\title{
Blackberry and redberry production in crop and intercrop in Pouso Alegre, southern Minas Gerais, Brazil
}

\author{
Produção de amora-preta e amora-vermelha na safra e \\ entressafra em Pouso Alegre, sul de Minas Gerais
}

\section{Csaignon Mariano Caproni ${ }^{\mathrm{I}}$ Paula Nogueira Curi ${ }^{\mathrm{II}}$ Pedro Henrique Abreu Moura ${ }^{\mathrm{III}}$ Rafael Pio $^{\text {IV }}$ Emerson Dias Gonçalves ${ }^{\mathrm{III}}$ Moacir Pasqual $^{\mathrm{IV}}$}

\section{ABSTRACT}

The cultivation of mulberry (Rubus sp.) is highly disseminated in cold climates, but some cultivars adapt to warm weather environments. The objective of the present study was to evaluate the production of blackberry and redberry in season and off season in Pouso Alegre, south of Minas Gerais. The experimental design was a randomized block, with twelve cultivars ('Arapaho', 'Xavante', 'Brazos', 'Tupy' 'Comanche', 'Choctaw', 'Guarani', 'Caingangue', 'Cherokee', 'Chicasaw'and 'Clone'and a redberry, three blocks and an experimental unit of four plants with a spacing of $0.5 \times 3.0 \mathrm{~m}$ and a total density of 6,666 plants per hectare. Conventional pruning was performed to produce the crop (October-December) and for off-season production (AprilJuly). In 'Brazos' there was increased production in the two seasons evaluated against other mulberry trees, conversely, in the off season, there was a positive effect of pruning carried out in January only in 'Tupy', 'Choctaw', 'Comanche' and 'Clone', with 'Tupy' presenting the highest productivity off season. In 'Brazos' and 'Tupy' there was the best balance between soluble solids and acidity in the crop and red berry in season. 'Brazos' and 'Cherokee' had the highest average content of total sugars. Due to the lack of supply of fruit, pruning mulberry trees in January is an alternative to increase the income of family-based farms.

Key words: Rubus $s p$. , yield, fruits quality.

RESUMO

O cultivo da amoreira (Rubus sp.) está amplamente expandido em regiões de clima frio, entretanto algumas cultivares se adaptam em ambientes de clima ameno. Objetivou-se com $o$ presente trabalho avaliar a produção de amoreira-preta $e$ amoreira-vermelha na safra e entressafra em Pouso Alegre, sul de Minas Gerais. $O$ delineamento experimental utilizado foi em blocos casualizados, com doze cultivares ('Arapaho', 'Xavante', 'Brazos', 'Tupy' 'Comanche', 'Choctaw', 'Guarani', 'Caingangue', 'Cherokee', 'Chicasaw', 'Clone' e uma amoreiravermelha), três blocos e unidade experimental de quatro plantas, espaçadas a 0,5x3,0m, totalizando uma densidade de 6.666 plantas por hectare. Visando à produção na safra (outubro a dezembro) e entressafra (abril a julho), foram realizadas, nos meses de janeiro e julho, as podas convencionais. Em 'Brazos', verificouse maior produção nas duas safras avaliadas em comparação com as demais amoreiras, já na entressafra, apenas em 'Tupy', 'Choctaw', 'Comanche' $e$ 'Clone'verificou-se efeito positivo da poda realizada em janeiro e produziram frutos "fora de época", sendo em 'Tupy' a maior produtividade na entressafra. Na 'Brazos' e 'Tupy', verificou-se o melhor equilibrio entre os sólidos solúveis e a acidez na safra e amora-vermelha na entressafra. 'Brazos' $e$ 'Cherokee' obtiveram teor médio de açúcares totais superiores. Devido à inexistência da oferta de frutos de amoreira, a poda realizada em janeiro se torna alternativa para o aumento da renda dos agricultores de base familiar.

Palavras-chave: Rubus sp., produtividade, qualidade dos frutos.

\section{INTRODUCTION}

In the Brazilian production of temperate climate fruit, which require cold winters, small fruits, except for strawberries are not yet very significant, but progress is being made (FACHINELLO et al., 2011). The main fruits in this group are strawberries, raspberries, blackberries and blueberries (CURI et al., 2014; MOURA et al., 2012; TIBERTI et al., 2015).

IEmpresa de Pesquisa Agropecuária de Minas Gerais (EPAMIG), Campo Experimental de Lambari (CELB), Lambari, MG, Brasil.

IIPrograma de Pós-graduação em Agronomia/Fitotecnia, Departamento de Agricultura (DAG), Universidade Federal de Lavras (UFLA), Lavras, MG, Brasil.

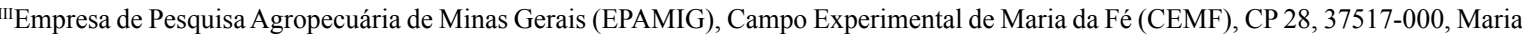
da Fé, MG, Brasil. E-mail: pedrohamoura@epamig.br. "Corresponding author.

${ }^{\mathrm{IV}}$ Departamento de Agricultura (DAG), Universidade Federal de Lavras (UFLA), Lavras, MG, Brasil. Received 04.29.15 Approved 02.22.16 Returned by the author 06.06.16 CR-2015-0623.R1 
In the south of Minas Gerais, strawberry production is consolidated and there is an increasing cultivation of other small fruits, especially blackberries, as an alternative for family farming, since it employs labor and can increase income (CAMPAGNOLO \& PIO, 2012a; PATTO et al., 2013; CURI et al., 2015a).

Blackberry production in Brazil goes from September to February, and there is no domestic offer of fruit outside this period (ANTUNES et al., 2010; CAMPAGNOLO \& PIO, 2012c; TULLIO \& AYUB, 2013). Production outside the peak times when this fruit is offered could be an economically useful option, as seen for other fruit, such as strawberries produced between January and March, which obtain high prices at this time of the year.

Health-related factors, such as phenolic compounds and carotenoids that can help combat degenerative diseases are present in blackberry (Rubus spp.) fruit, and are responsible for a growing interest in the consumption of these fruits in recent years (ALI et al., 2011; SOUZA et al., 2014). In addition anthocyanins can be highlighted, since they confer an attractive color in processing these fruit (GUEDES et al., 2013; MARO et al., 2014).

In Lavras, in the south of Minas Gerais (Cwb mesothermal or tropical highland climate, according to the Köppen classification), a mean productivity of $12,379,1 \mathrm{~kg} \mathrm{ha}^{-1}$ was recorded during the first productive cycle for the 'Brazos' cultivar, and this was surpassed during the second year of production with 20,032.1 $\mathrm{kg} \mathrm{ha}^{-1}$ (CURI et al., 2015a). Other outstanding cultivars in the region were 'Tupy', with an estimated productivity of $9,031.41 \mathrm{~kg}$ $\mathrm{ha}^{-1}$ in the first year of production and $13,832.7 \mathrm{~kg}$ $\mathrm{ha}^{-1}$ in the second, and 'Guarani' with 7,593.1 $\mathrm{kg} \mathrm{ha}^{-1}$ and $16,927.5 \mathrm{~kg} \mathrm{ha}^{-1}$ produced in the first and second years respectively (CURI et al., 2015a).

This fruit also adapted well to the Plateau conditions of Poços de Caldas-MG (Cwa subtropical climate), where the estimated productivity of 'Brazos' cultivar attained $25,238 \mathrm{~kg}$ ha $^{-1}$ (ANTUNES et al., 2000).

These results in the south of Minas Gerais have been much higher than those found in the colder regions of Brazil, and show how well the blackberry has adapted to these climatic conditions (GUEDES et al., 2013). According to CAMPAGNOLO \& PIO (2012b), at Santa Helena-PR (Cfa humid subtropical zone climate), the maximum productivity achieved with 'Tupy' was $6,430 \mathrm{~kg} \mathrm{ha}^{-1}$. Conversely in PelotasRS, ANTUNES et al. (2010) using a planting density of $3.5 \times 0.7 \mathrm{~m}$ the estimated productivity was $5,169 \mathrm{~kg}$ ha $^{-1}$ for 'Tupy' and only $2,794 \mathrm{~kg} \mathrm{ha}^{-1}$ for 'Brazos'.
The advance of areas where blackberries are cultivated, especially in the Southeast region, in places that are not very cold in winter, call attention to the importance of evaluating the performance of cultivars in new microclimates. It is also necessary to quantify the production and quality of the redberry (R. rosifolius) which is a native species of the Mantiqueira mountains in Brazil (CAMPAGNOLO \& PIO, 2012c).

Besides considering the high productivity and quality of the fruit as essential factors in cultivation, it is also necessary to increase experimentation with new techniques that can allow the farmer to improve these characteristics. Among the techniques, the effect of different pruning times may be a practice to evaluate whether the pruning period has an influence on productive seasonality, production and qualitative characteristics of the fruit.

Thus, the purpose of this study was to evaluate production, productivity and quality of fruits of different blackberry cultivars and one redberry, submitted to two different pruning times with production during the harvest and off season periods in the region of Pouso Alegre, south of Minas Gerais.

\section{MATERIALS AND METHODS}

The experiment was perfomed at Pouso Alegre Experimental Farm belonging to Empresa de Pesquisa Agropecuária de Minas Gerais (EPAMIG), during the period from July 2011 to April 2013. The climate of this municipality is classified according to Köppen as being of the Cwa type, i.e., hot temperate climate (mesothermal), with a dry winter and rainy summer (KOTTEK et al., 2006). It is characterized by presenting an annual mean temperature of around $19.2^{\circ} \mathrm{C}$, mean relative humidity of $75 \%$, annual precipitation of approximately $1,744 \mathrm{~mm}$ and mean altitude of 882 meters.

Treatments tested corresponded to eleven different blackberry cultivars: 'Arapaho', 'Xavante', 'Brazos', 'Tupy' 'Comanche', 'Choctaw', 'Guarani', 'Caingangue', 'Cherokee', 'Chicasaw' and 'Clone'; and one redberry, a species native to the Mantiqueira mountains in Brazil. Seedlings taken to the field in February 2011 and planted with a $0.5 \times 3.0$ meters spacing (density of 6,666 plants per hectares), were acquired from the horticulture sector at the Universidade Federal de Lavras (UFLA), where they were produced from cuttings according to the methodology of TIBERTI et al. (2015). During vegetative growth, the plants were conducted under a simple espalier by means of a layer of two parallel 
wires (CURI et al., 2015a). After the seedlings were established a drip irrigation system was implemented.

Pruning was performed in the months of January and July, during the two years studied, aiming to produce in season and off season. The pruning methodology was similar to that used by CAMPAGNOLO \& PIO (2012b) in conventional pruning. Pruning was also performed to clear the excess branches located about $30 \mathrm{~cm}$ above ground level and the stems located at the plant base were also removed.

The experimental design used was randomized blocks, containing 12 treatments (11 cultivars of blackberry and one redberry), with three blocks and four useful plants per experimental unit. During the experiment the spontaneous plants were controlled and solid composting applied $(3 \mathrm{~kg}$ per linear meter) in October and December of each cycle (2011 and 2012), this being a decomposed mixture of plant material and cattle manure at a proportion of $3: 1$. In those two years, the soil was analyzed using the Mehlich 1 method and the necessary corrections performed. This management was the same used by CURI et al. (2015b).

During the first production cycle, the productive variables for production $\left(\mathrm{g}\right.$ plant $\mathrm{t}^{-1}$ ) and estimated productivity $\left(\mathrm{kg} \mathrm{ha}^{-1}\right)$, were evaluated in the crop from October to December 2011, and in the off season crop from April to July 2012; in the second cycle production was evaluated only for the crop from October to December 2012. Fruits harvested per plot every three days were counted and weighed using a semi-analytic balance. At the end of the cycle, all the fruits and all masses recorded were added up to determine production per plant and estimated productivity.

During the full harvest, in the crop time and off season, 20 fruits per plot were carefully placed on transparent terephthalate polyethylene trays, placed in styrofoam boxes with ice and transported to the laboratory for physicalchemical testing at the Universidade do Vale do Sapucaí (UNIVAS) in Pouso Alegre, MG, where the following chemical tests were performed: soluble solids (SS), with the help of a portable refractometer (model RTD-45, Cial, São Paulo, $\mathrm{SP}$ ), with a reading expressed in ${ }^{\circ}$ Brix; titratable acidity (TA), obtained by titrating the samples with solutions of $\mathrm{NaOH} 0,1 \mathrm{~N}$, expressed in \% of citric acid; $\mathrm{pH}$; soluble solids to acidity ratio (RATIO) and total sugars in which the extractions were performed using the Lane-Enyon method cited by the AOAC (2005), and total sugars determined according to the technique of Somogy, adapted by NELSON (1944). The reading was performed using a Beckman 640 B spectrophotometer with computerized systems and the results were expressed in percentage (g per $100 \mathrm{~g}$ of pulp).

When all the tests were finished, the data were submitted to analysis of variance and means compared using the Scott-Knott test, with a level of $5 \%$ probability of error.

\section{RESULTS AND DISCUSSION}

Analyzing the productive performance of the eleven blackberry and the redberry cultivars, it was reported that the 'Brazos' cultivar was the most productive and statistically distinguished from the other cultivars. With a production of $2,080 \mathrm{~g}$ per plant, the estimated productivity was $13,865 \mathrm{~kg} \mathrm{ha}^{-1}$ in the first productive cycle (Table 1). This result is superior to that reported by CURI et al. (2015a) who reported an estimated productivity of $12,379,1 \mathrm{~kg} \mathrm{ha}^{-1}$ for this cultivar in the first productive cycle in Lavras-MG.

An interesting fact when two productive cycles are examined is that even though the 'Brazos' cultivar is the most productive, it was the only cultivar in which productivity diminished in the second cycle, when it produced 8,950 $\mathrm{kg} \mathrm{ha}^{-1}$. Even so this productivity was $21 \%$ greater than that of the second most productive cultivar, 'Comanche' which had an estimated productivity of $7,384 \mathrm{~kg}$ $\mathrm{ha}^{-1}$ (Table 1). This drop in production from the first to the second year did not occur for the 'Brazos' cultivar in the study by CURI et al. (2015a), It produced $20,032,1 \mathrm{~kg} \mathrm{ha}^{-1}$, but this occurred with other cultivars such as 'Choctaw' and redberry.

After the 'Brazos' cultivar, the most productive were 'Guarani', 'Clone' and 'Tupy' in the 2011/12 productive cycle, and 'Comanche', 'Tupy', 'Caingangue', 'Guarani' and 'Clone' in the 2012/13 productive cycle (Table 1). These cultivars are also among the most productive in the studies by CURI et al. (2015a) and TADEU et al. (2015) in Lavras-MG and in the study by CAMPAGNOLO \& PIO (2012a) in Marechal Cândido Rondon-PR.

CURI et al. (2015a) described 'Tupy', 'Guarani', 'Caingangue', 'Brazos' and 'Comanche' as the best recommended for the South of Minas, but call attention to the importance of performing studies to select these and other cultivars at different sites.

According to table 2, results show that for some cultivars fruit can be produced off season by adopting early pruning. 'Tupy' had the highest off season production $\left(188 \mathrm{~g}\right.$ planta $\left.^{-1}\right)$. Next the 'Clone' and 'Comanche' cultivars each produced $73 \mathrm{~g}$ plant $^{-1}$ and 'Choctaw' produced $72 \mathrm{~g}$ plant ${ }^{-1}$. Other cultivars 
Table 1 - Production, estimated productivity, soluble solids (SS), pH, titratable acidity, SS/Acidity ratio (RATIO) and total sugars in blackberry and redberry cultivars produced at Pouso Alegre, in the south of Minas Gerais, in the crop of productive cycles 2011/12 and 2012/13. EPAMIG, Pouso Alegre/MG, 2015.

\begin{tabular}{|c|c|c|c|c|c|c|c|}
\hline Cultivar & Production (g) & $\begin{array}{l}\text { estimated productivity } \\
\left(\mathrm{Kg} \mathrm{ha}^{-1}\right)\end{array}$ & $\begin{array}{l}\text { soluble solids } \\
\text { (SS) }\left({ }^{\circ} \text { Brix }\right)\end{array}$ & $\mathrm{pH}$ & $\begin{array}{l}\text { titratable acidity } \\
\left(\mathrm{g} 100 \mathrm{~g}^{-1}\right)\end{array}$ & $\begin{array}{l}\text { SS/Acidity ratio } \\
\text { (RATIO) }\end{array}$ & $\begin{array}{l}\text { Total sugars } \\
\left(\mathrm{g} 100 \mathrm{~g}^{-1}\right)\end{array}$ \\
\hline \multicolumn{8}{|c|}{ 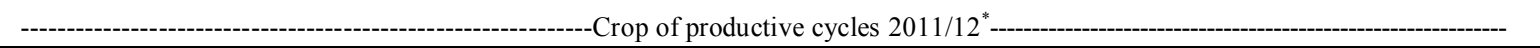 } \\
\hline $\begin{array}{l}\text { 'Amora } \\
\text { Vermelha' }\end{array}$ & $65 \mathrm{e}$ & $433 \mathrm{e}$ & $11.5 \mathrm{a}$ & $3.56 \mathrm{~b}$ & $1.6 \mathrm{~b}$ & $7.2 \mathrm{c}$ & $3.1 \mathrm{~b}$ \\
\hline 'Brazos' & $2,080 \mathrm{a}$ & $13,865 \mathrm{a}$ & $11.0 \mathrm{~b}$ & $3.52 \mathrm{c}$ & $1.1 \mathrm{~d}$ & $10.0 \mathrm{a}$ & $3.2 \mathrm{a}$ \\
\hline ‘Tupy’ & $210 \mathrm{c}$ & $1.400 \mathrm{c}$ & $10.5 \mathrm{c}$ & $3.33 \mathrm{~h}$ & $1.5 \mathrm{~b}$ & $7.0 \mathrm{c}$ & $2.7 \mathrm{c}$ \\
\hline 'Comanche' & $134 \mathrm{~d}$ & $891 \mathrm{~d}$ & $10.0 \mathrm{~d}$ & $3.40 \mathrm{e}$ & $1.6 \mathrm{~b}$ & $6.3 \mathrm{~d}$ & $2.0 \mathrm{f}$ \\
\hline 'Xavante' & $34 \mathrm{e}$ & $223 \mathrm{e}$ & $9.5 \mathrm{e}$ & $3.36 \mathrm{f}$ & $1.5 \mathrm{~b}$ & $6.3 \mathrm{~d}$ & $2.7 \mathrm{c}$ \\
\hline 'Choctaw' & $33 \mathrm{e}$ & $217 \mathrm{e}$ & $9.5 \mathrm{e}$ & $3.31 \mathrm{j}$ & $1.3 \mathrm{c}$ & $7.3 \mathrm{c}$ & $2.5 \mathrm{~d}$ \\
\hline 'Guarani' & $285 \mathrm{~b}$ & $1,903 \mathrm{~b}$ & $9.5 \mathrm{e}$ & $3.66 \mathrm{a}$ & $1.0 \mathrm{e}$ & $9.5 \mathrm{a}$ & $3.1 \mathrm{~b}$ \\
\hline 'Caingangue' & $5 \mathrm{e}$ & $30 \mathrm{e}$ & $9.0 \mathrm{f}$ & $3.50 \mathrm{~d}$ & $1.1 \mathrm{~d}$ & $8.2 \mathrm{~b}$ & $2.7 \mathrm{c}$ \\
\hline 'Chicasaw' & $25 \mathrm{e}$ & $169 \mathrm{e}$ & $9.0 \mathrm{f}$ & $3.32 \mathrm{i}$ & $2.2 \mathrm{a}$ & $4.1 \mathrm{f}$ & $1.7 \mathrm{~g}$ \\
\hline 'Arapaho' & $19 \mathrm{e}$ & $127 \mathrm{e}$ & $8.5 \mathrm{~g}$ & $3.30 \mathrm{k}$ & $1.5 \mathrm{~b}$ & $5.7 \mathrm{e}$ & $1.4 \mathrm{~h}$ \\
\hline 'Clone' & $225 \mathrm{c}$ & $1,497 \mathrm{c}$ & $8.5 \mathrm{~g}$ & $3.34 \mathrm{~g}$ & $1.5 \mathrm{~b}$ & $5.7 \mathrm{e}$ & $2.13 \mathrm{e}$ \\
\hline 'Cherokee',** & $2 \mathrm{e}$ & $10 \mathrm{e}$ & - & - & - & - & - \\
\hline CV (\%) & 7.00 & 7.00 & 1.55 & 0.09 & 3.82 & 3.43 & 1.49 \\
\hline \multicolumn{8}{|c|}{ 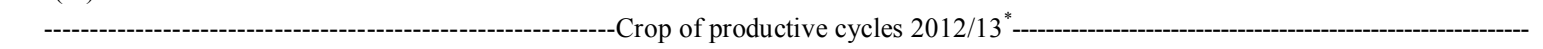 } \\
\hline $\begin{array}{l}\text { 'Amora } \\
\text { vermelha' }\end{array}$ & $71 \mathrm{e}$ & $470 \mathrm{e}$ & $11.6 \mathrm{a}$ & $3.57 \mathrm{a}$ & $1.6 \mathrm{a}$ & $7.2 \mathrm{c}$ & $3.0 \mathrm{e}$ \\
\hline 'Brazos' & $1,343 \mathrm{a}$ & $8,950 \mathrm{a}$ & $7.8 \mathrm{~d}$ & $3.21 \mathrm{~d}$ & $1.1 \mathrm{e}$ & $7.3 \mathrm{c}$ & $4.1 \mathrm{c}$ \\
\hline ‘Tupy’ & $915 \mathrm{c}$ & $6,100 \mathrm{c}$ & $6.6 \mathrm{f}$ & $3.35 \mathrm{~b}$ & $0.9 \mathrm{f}$ & $7.1 \mathrm{c}$ & $3.5 \mathrm{~d}$ \\
\hline 'Comanche' & $1,108 \mathrm{~b}$ & $7,384 \mathrm{~b}$ & $6.6 \mathrm{f}$ & $3.12 \mathrm{e}$ & $1.2 \mathrm{~d}$ & $5.5 \mathrm{~d}$ & $3.0 \mathrm{e}$ \\
\hline 'Xavante' & $247 d$ & $1,645 \mathrm{~d}$ & $7.8 \mathrm{~d}$ & $3.15 \mathrm{e}$ & $1.4 \mathrm{~b}$ & $5.7 \mathrm{~d}$ & $4.0 \mathrm{c}$ \\
\hline 'Choctaw' & $406 \mathrm{~d}$ & $2,706 \mathrm{~d}$ & $7.8 \mathrm{~d}$ & $3.22 \mathrm{~d}$ & $1.0 \mathrm{f}$ & $8.1 \mathrm{~b}$ & $4.2 \mathrm{c}$ \\
\hline 'Guarani' & $880 \mathrm{c}$ & $5,867 \mathrm{c}$ & $7.2 \mathrm{e}$ & $3.11 \mathrm{e}$ & $1.3 \mathrm{c}$ & $5.7 \mathrm{~d}$ & $2.9 \mathrm{f}$ \\
\hline 'Caingangue' & $897 \mathrm{c}$ & $5,978 \mathrm{c}$ & $8.1 \mathrm{c}$ & $3.34 \mathrm{~b}$ & $0.9 \mathrm{f}$ & $8.7 \mathrm{~b}$ & $4.3 \mathrm{~b}$ \\
\hline 'Chicasaw' & $233 \mathrm{~d}$ & $1,550 \mathrm{~d}$ & $6.6 \mathrm{f}$ & $3.16 \mathrm{e}$ & $1.3 \mathrm{c}$ & $5.2 \mathrm{~d}$ & $3.0 \mathrm{e}$ \\
\hline 'Arapaho' & $223 d$ & $1,483 \mathrm{~d}$ & $8.4 \mathrm{c}$ & $3.47 \mathrm{a}$ & $1.0 \mathrm{f}$ & $8.6 \mathrm{~b}$ & $4.1 \mathrm{c}$ \\
\hline 'Clone' & $823 \mathrm{c}$ & $5,484 \mathrm{c}$ & $6.6 \mathrm{f}$ & $3.16 \mathrm{e}$ & $1.0 \mathrm{e}$ & $6.3 \mathrm{~d}$ & $3.2 \mathrm{e}$ \\
\hline 'Cherokee' & $244 d$ & $1,628 \mathrm{~d}$ & $9.0 \mathrm{~b}$ & $3.27 \mathrm{c}$ & $0.8 \mathrm{~g}$ & $11.8 \mathrm{a}$ & $9.6 \mathrm{a}$ \\
\hline C.V. (\%) & 20.47 & 20.47 & 2.55 & 0.64 & 1.45 & 3.45 & 1.68 \\
\hline
\end{tabular}

*Means followed by the same letter are not different from each other according to the Scott-Knott test $(\mathrm{P} \leq 0.05)$.

*** In the crop of productive cycle 2011/12 the 'Cherokee' cultivar did not produce sufficient fruit to perform the chemical analyses.

did not produce anything during the off season that resulted from the January pruning. These results indicated that the 'Tupy' cultivar is best adapted to off season production in the climatic conditions of Pouso Alegre-MG. In the Caldas-MG region, according to ANTUNES (2006), the blackberry cultivars that best adapted to off season production were also 'Tupy' and 'Comanche'.

As to the quality of the fruit produced, according to ALI et al. (2011), depending on the place and time when the blackberries are cultivated, there may be variations in the contents of chemical compounds caused by differences as to the intensity of solar radiation and thermal range that influence the organoleptic characteristics of these fruits. Fruits that presented the lowest acidity in this crop were the 'Guarani' cultivars in the first cycle; these results agree with TADEU et al. (2015) and 'Cherokee' in the second cycle, while the most acid fruits were from the 'Chicasaw' cultivar in the first cycle and from the redberry in the second cycle (Table 1). In Lavras-MG, the redberry also presented the highest acidity of the fruits in the second productive cycle evaluated by CURI et al. (2015). In the off season of the $2011 / 12$ productive cycle, among the producing cultivars, 'Clone' had the most acid fruit (Table 2).

Redberry had the highest soluble solids content in the crop of the two productive cycles, 
Table 2 - Production, estimated productivity, soluble solids (SS), pH, titratable acidity, SS/Acidity ratio (RATIO), and total sugars in blackberry and redberry cultivars produced at Pouso Alegre, in the south of Minas Gerais, during the off-season of the productive cycle 2011/12. EPAMIG, Pouso Alegre/MG, 2015.

\begin{tabular}{|c|c|c|c|c|c|c|c|}
\hline Cultivar & Production $(\mathrm{g})$ & $\begin{array}{l}\text { estimated } \\
\text { productivity } \\
\left(\mathrm{Kg} \mathrm{ha}^{-1}\right)\end{array}$ & $\begin{array}{l}\text { soluble solids }(\mathrm{SS}) \\
\left({ }^{\circ} \mathrm{Brix}\right)\end{array}$ & $\mathrm{pH}$ & $\begin{array}{l}\text { titratable acidity } \\
\left.100 \mathrm{~g}^{-1}\right)\end{array}$ & $\begin{array}{l}\text { SS/Acidity } \\
\text { ratio (RATIO) }\end{array}$ & $\begin{array}{l}\text { Total sugars } \\
\left(\mathrm{g} 100 \mathrm{~g}^{-1}\right)\end{array}$ \\
\hline ‘Tupy’ & $188 \mathrm{a}$ & $1,250 \mathrm{a}$ & $7.2 \mathrm{a}$ & $3.05 \mathrm{a}$ & $1.5 \mathrm{c}$ & $4.7 \mathrm{a}$ & $7.2 \mathrm{a}$ \\
\hline 'Comanche' & $73 \mathrm{~b}$ & $483 \mathrm{~b}$ & $6.6 \mathrm{~b}$ & $2.92 \mathrm{~b}$ & $1.6 \mathrm{~b}$ & $4.2 \mathrm{a}$ & $6.0 \mathrm{c}$ \\
\hline 'Choctaw' & $72 b$ & $481 \mathrm{~b}$ & $7.5 \mathrm{a}$ & $3.06 \mathrm{a}$ & $1.4 \mathrm{~d}$ & $5.4 \mathrm{~b}$ & $6.1 \mathrm{~b}$ \\
\hline 'Clone' & $73 \mathrm{~b}$ & $483 \mathrm{~b}$ & $6.3 \mathrm{~b}$ & $2.89 \mathrm{c}$ & $2.0 \mathrm{a}$ & $3.2 \mathrm{c}$ & $6.1 \mathrm{~b}$ \\
\hline C.V. (\%) & 5.08 & 5.08 & 3.59 & 0.29 & 1.18 & 3.41 & 0.33 \\
\hline
\end{tabular}

"Means followed by the same letter are not different from each other according to the Scott-Knott test $(\mathrm{P} \leq 0,05)$. In the off season of the 2011/12 productive cycle the redberry and blackberry cultivars 'Brazos', 'Xavante', 'Guarani', 'Caingangue', 'Chicasaw', 'Arapaho' and 'Cherokee' did not produce fruits and therefore are not in table 2.

attaining $11.5^{\circ}$ Brix in both. These results are higher than those presented by CURI et al. (2015a), who reported $11.1^{\circ}$ Brix (Table 1). Considering that the redberry did not produce fruits off season, the blackberry cultivars 'Choctaw' and 'Tupy' presented the highest soluble solids content in that season (7.5 and $7.2^{\circ}$ Brix) respectively (Table 2 ). These values were higher than those of the other cultivars off season, but lower than the soluble solids found by CAMPAGNOLO \& PIO (2012b), who reported $10^{\circ}$ Brix contents for the 'Tupy' cultivar when conventional pruning was performed.

Analyzing the relationship between the concentration of soluble solids and acidity (RATIO), it wasreported the highest values for 'Brazos' and 'Guarani' cultivars in the 2011/12 production cycle, and for 'Cherokee' in the 2012/13 cycle, both of them considering the production of the normal crop (Table 1). Considering the off season production in the 2011/12 cycle, the highest RATIO was for the 'Choctaw' blackberry (Table 2). This ratio helps indicate for which purpose the fruit are to be used. A high ratio between soluble solids and acidity suggested fruits for consumption, such as fresh fruit, a low ratio suggests fruits for industrial processing.

The determination of the fruit $\mathrm{pH}$ is also an important factor in defining the purpose for which the cultivars are to be used. According to studies performed, it was observed that 'Guarani' had the highest $\mathrm{pH}$ (3.66) and is most appropriate for industry. Conversely, 'Arapaho' had the lowest $\mathrm{pH}$ (3.30) and is the most appropriate to be consumed raw (Table 1).

As to the total sugar content, 'Brazos'

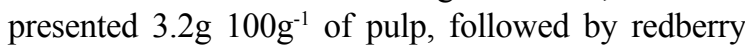

and 'Guarani'. These were the highest contents in the 2011/12 crop. For the next crop the highest content was

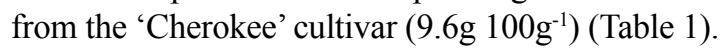

\section{CONCLUSION}

Due to greater adaptability in the Pouso Alegre-MG region, 'Brazos' was the most productive cultivar of the two crops evaluated. A positive effect for fruit production during the off season was reported in 'Tupy' which was pruned in January, and the use of this technique allows increasing the farmers' income. Cultivars 'Brazos', 'Guarani' and 'Cherokee' presented the highest ratio between soluble solids and acidity, suggesting that their fruits can be enjoyed raw.

\section{ACKNOWLEDGEMENTS}

To the Coordenação de Aperfeiçoamento de Pessoal de Nível Superior (CAPES), Conselho Nacional de Desenvolvimento Científico e Tecnológico (CNPq), and Fundação de Amparo à Pesquisa do Estado de Minas Gerais (FAPEMIG) for the financial support in the development of the present study.

\section{REFERENCES}

ASSOCIATION OF OFFICIAL ANALYTICAL CHEMISTS. Official methods of analysis of AOAC international. 18.ed. Maryland, 2005. v. 2. Available from: <http://pt.scribd.com/ doc/131064441/AOAC-2005\#scribd>. Accessed: Dec. 12, 2011.

ALI, L. et al. Late season harvest and storage of Rubus berries Major antioxidant and sugar levels. Scientia Horticulturae, v.129, n.3, p.376-381, 2011. Available from: <http://www.sciencedirect. com/science/article/pii/S0304423811001701>. Accessed: Feb. 10, 2014. doi: 10.1016/j.scienta.2011.03.047.

ANTUNES, L.E.C. et al. Phenology and production of blackberry cultivars in agroecological system. Ciência Rural, v.40, n.9, 
p.1929-1933, 2010. Available from: <http://www.scielo.br/scielo. php? pid $=$ S0103-84782010000900012\&script $=$ sci_arttext $>$. Accessed: Mar. 24, 2014. doi: 10.1590/S0103-84782010000900012.

ANTUNES, L.E.C. et al. Fenologia e produção de variedades de amorapreta nas condições do Planalto de Poços de Caldas-MG. Revista Brasileira de Fruticultura, v.22, n.1,p.89-95, 2000. Available from: $<\mathrm{http}: /$ www.scielo.br/scielo.php?script $=$ sci_nlinks\&ref $=000071 \&$ pid $=$ S0100$2945200600030002000005 \& \operatorname{lng}=$ en $>$. Accessed: Feb. 10, 2014.

ANTUNES, L.E.C. et al. Off season production of blackberries varieties. Revista Brasileira de Fruticultura, v.28, n.3, p.430-434, 2006. Available from: $<$ http://www.scielo.br/scielo.php?script=sci arttext\&pid $=$ S0100-29452006000300020 $>$. Accessed: Apr. 09, 2015. doi: 10.1590/S0100-29452006000300020.

CAMPAGNOLO, M.A.; PIO, R. Phenological and yield performance of black and redberry cultivars in western Paraná State. Acta Scientiarum7 Agronomy, v.34, n.4, p.439-444, 2012a Available from: $<$ http://www.scielo.br/scielo.php?pid=S180786212012000400011\&script=sci_arttext $>$. Accessed: Apr. 13, 2015. doi: 10.4025/actasciagron.v34i4.15528.

CAMPAGNOLO, M.A.; PIO, R. Drastic pruning for the production of blackberry in subtropical regions. Pesquisa Agropecuária Brasileira, v.47, n.7, p.934-938, 2012b. Available from: <http://www.scielo.br/scielo.php?pid=S0100204X2012000700009\&script $=$ sci_arttext $>$. Accessed: Apr. 10 , 2015. doi: 10.1590/S0100-204X2012000700009.

CAMPAGNOLO, M.A.; PIO, R. Productive of 'Tupy' blackberry under different pruning time. Ciência Rural, v.42, n.2, p.225231, 2012c. Available from: <http://www.scielo.br/scielo. php? script $=$ sci_arttext\&pid $=$ S0103-84782012000200007>. Accessed: June 02,2014. doi: 10.1590/S0103-84782012005000007.

CURI, P.N. et al. Quality raspberries with and without plastic covering over the canopy in different spacing. Revista Brasileira de Fruticultura, v.36, n.1, p.199-205, 2014. Available from: $<$ http://www.scielo.br/scielo.php?script=sci_arttext\&pid=S010029452014000100023\&lng=pt\&nrm=iso\&tlng=en>. Accessed Apr. 06, 2015. doi: 10.1590/0100-2945-234/13

CURI, P.N. et al. Production of blackberry and redberry in Lavras - MG, Brazil. Ciência Rural, v.45, n.8, p.1368-1374, 2015a. Available from: <http://www.scielo.br/scielo.php?pid=S010384782015005031572\&script $=$ sci_arttext $>$. Accessed: Oct. 15, 2015. doi: $10.1590 / 0103-8478 \mathrm{cr} 20131572$.

CURI, P.N. et al. Production and quality of raspberries 'Batum' cultivated under cover plastic and two spacing in subtropical area. Ciência Rural, v. 45, n.11, p.1994-2000, 2015b. Available from: $<$ http://coral.ufsm.br/ccr/revista/artigos/CR-2014-1636.R2.pdf> Accessed: Oct. 15, 2015. doi: 10.1590/0103-8478cr20141636.

FACHINELLO, J.C. et al. Situation and perspectives of temperate fruit crops in Brazil. Revista Brasileira de Fruticultura, v. 33, n. esp, p.109-120, 2011. Available from: $<$ http://www.scielo.br/scielo. php? script $=$ sci arttext\&pid $=$ S0100-29452011000500014\&lng $=$ pt\&nrm=iso\&tlng=en>. Accessed: Jun. 10, 2014. doi: 10.1590/ S0100-29452011000500014.

GUEDES, M.N.S. et al. Chemical characterization and minera levels in the fruits of blackberry cultivars grown in a tropical climate at an elevation. Acta Scientiarum. Agronomy, v.32, n.2, p.191-196, 2013. Available from: <http://www.scielo.br/ scielo.php?pid=S1807-86212013000200007\&script $=$ sci_arttext $>$. Accessed: Nov. 05, 2013. doi: 10.4025/actasciagron.v35i2.16630.

KOTTEK, M. et al. World map of the Köppen-Geiger climate classification updated. Meteorologische Zeitschrift, v.15, n.3, p.259-263, 2006. Available from: <http://koeppen-geiger.vuwien.ac.at/pdf/Paper_2006.pdf $>$. Accessed: Apr. 09, 2015. doi: 10.1127/0941-2948/2006/0130.

MARO, L.A.C. et al. Environmental and genetic variation in the post-harvest quality of raspberries in subtropical areas in Brazil. Acta Scientiarum. Agronomy, v.36, n.3, p.323-328, 2014. Available from: <http://periodicos.uem.br/ojs/index.php/ ActaSciAgron/article/view/18050>. Accessed: Apr. 06, 2015. doi: 10.4025/actasciagron.v36i3.18050.

MOURA, P.H.A. et al. Phenology and yield of raspberry cultivars in subtropical regions in Brazil. Pesquisa Agropecuária Brasileira, v.47, n.12, p.1714-1721, 2012. Available <from://www.scielo. br/scielo.php?pid $=$ S0100-204X2012001200006\&script $=$ sci arttext $>$. Accessed: Jun. 10, 2014. doi: 10.1590/S0100204X2012001200006

NELSON, N. A photometric adaptation of the somogyi method for the determination of glucose. Journal of Biological Chemists, v.153, n.1, p.375-380, 1944. Available from: <http://www.jbc.org/ content/153/2/375.full.pdf+html>. Accessed: June 10, 2014

PATTO, L.S. et al. Vegetative propagation of redberry using refrigeration, IBA and BAP. Revista de Ciências Agrárias/ Amazonian Journal of Agricultural and Environmental Sciences, v.56, n.supl, p.140-144, 2013. Available from: $<$ https:// periodicos.ufra.edu.br/index.php?journal $=$ ajaes \&page $=$ article $\&$ o $\mathrm{p}=$ view\&path $\% 5 \mathrm{~B} \% 5 \mathrm{D}=1441>$. AccessED: jan. 05, 2014. doi: $10.4322 /$ rca.2013.094

SOUZA, V.R. et al. Determination of the bioactive compounds, antioxidant activity and chemical composition of Brazilian blackberry, red raspberry, strawberry, blueberry and sweet cherry fruits. Food Chemistry, v.156, p.362-368, 2014. Available from: <http://ac.elscdn.com/S0308814614001770/1-s2.0-S0308814614001770-main. pdf? tid=f1425554-bbf4-11e3-aa89-00000aab0f6b\&acdnat $=13966$ 14824 0da62cdedaf5c9f85864d781725edb24>. Accessed: apr. 13 2015. doi: 10.1016/j.foodchem.2014.01.125.

TADEU, M.H. et al. Drastic summer pruning and production of blackberry cultivars in subtropical areas. Pesquisa Agropecuária Brasileira, v.50, n.2, p.132-140, 2015. Available from: < http://seer. sct.embrapa.br/index.php/pab/article/view/19856>. Accessed: Apr. 09, 2015. doi: 10.1590/S0100-204X2015000200005.

TIBERTI, A.S. et al. Cold storage and treatment with plant growth regulators in rooting of root and stems cutting of raspberry. Ciência Rural, v.45, n.8, p.1445-1450, 2015. Available from: <http:// www.scielo.br/scielo.php? script $=$ sci_arttext\&pid $=$ S0103$84782015000801445 \& \operatorname{lng}=\mathrm{pt} \& \mathrm{nrm}=\mathrm{iso} \& \mathrm{t} \operatorname{lng}=\mathrm{pt}>$. Accessed: Oct. 15,2015 . doi: $10.1590 / 0103-8478 \mathrm{cr} 20131502$.

TULLIO, L.; AYUB, R.A. Production of blackberry cv tupy, depending on the intensity of pruning. Semina: Ciências Agrárias, v.34, n.3, p.1147-1152, 2013. Available from: $<$ http://www.uel.br/revistas/uel/index.php/semagrarias/ article/view/10109>. Accessed: Apr. 13, 2015. doi: 10.5433/1679-0359.2013v34n3p1147. 